\title{
Association of Nephrotic Syndrome with Intestinal Lymphangiectasia
}

\author{
J. SALAZAR DE SOUSA, O. GUERREIRO, A. CUNHA, and J. ARAÚJO \\ From Clínica Pediátrica Universitária, Lisbon, Portugal
}

The occurrence of exudative enteropathy in children with the nephrotic syndrome was first reported by Nusslé et al. in 1961, but no intestinal pathology has previously been described in nephrotic children, whether with or without protein-losing enteropathy. The finding in small bowel biopsy specimens of intestinal lymphangiectasia, in 4 of 7 cases of nephrotic syndrome, suggests that this association might not be uncommon.

\section{Material and Methods}

Seven children aged from 10 months to 10 vears, admitted to the Clínica Pediátrica Universitária de Lisboa with nephrotic syndrome, were submitted to intestinal biopsy, using the paediatric version of the Crosby-Kugler capsule (Crosby and Kugler, 1957), and following a technique previously described (Salazar de Sousa and Cunha, 1967). The specimens were fixed in buffered formalin and stained with haematoxylin-eosin.

In 2 patients the intestinal loss of plasma protein was studied with ${ }^{131}$ I albumin (RISA, Abbott Laboratories) according to the method of Jeejeebhoy and Coghill (1961).

\section{Results}

Clinical and biochemical details of Cases 1-4 are summarized in Tables I and II. The results of renal biopsy and intestinal biopsy are given in Table $I$, and illustrated in Fig. 1-4.

Table III gives the results of RISA studies in Cases 2 and 4 . Protein loss from the gut was $13 \%$ and $8 \%$ per day, compared with $2 \%$ per day in a control case.

Cases 5-7 need be mentioned only briefly.

Case 5. A 6-year-old boy with a pure nephrosis that responded well to steroid therapy.

Case 6. A 4-year-old girl with a pure nephrosis that responded well to steroid therapy.

Case 7. A 10-month-old boy with a familial form of nephrosis. A (surgical) renal biopsy showed a

Received August 17, 1967. lobular glomerulonephritis. $\mathrm{He}$ proved non-responsive to steroids.

Jejunal biopsy in Cases 5, 6, and 7 showed a marked oedema of the lamina propria as the sole abnormality.

\section{Discussion}

Though intestinal protein loss during the acute phase of the nephrotic syndrome is an accepted fact (Nusslé et al., 1961; Royer et al., 1963), there is no previous reference to the association of nephrosis and intestinal lymphangiectasia. Nor, in two recent review articles of protein-losing enteropathy (Dawson, 1965; Waldmann, 1966), is the nephrotic syndrome referred to in the list of diseases in which intestinal lymphangiectasia may be found.

Of 7 children with the nephrotic syndrome submitted to intestinal biopsy, the histological picture was typical of intestinal lymphangiectasia in 2 (Cases 2 and 4), and was consistent with this diagnosis in two others (Cases 1 and 3). In the authors' experience of over 200 intestinal biopsies in children, lymphatic dilatation of such a magnitude as that seen in Cases 1 and 3 has never been seen.

In the 2 cases (Cases 2 and 4 ) in which the metabolism of albumin was studied with RISA, the faecal loss of labelled albumin was found to be much increased.

We conclude that since protein-losing enteropathy is a frequent occurrence during the acute phase of the nephrotic syndrome, in at least some of these cases, intestinal lymphangiectasia is the responsible factor.

The finding of intestinal lymphangiectasia in nephrotic children has some interesting therapeutic implications. Long-chain fatty acids are largely converted to chylomicrons which are transported by the intestinal lymph, whereas short-chain fatty acids of 10 carbon atoms or less are mainly found in the portal blood (Peterson, 1963). With a low fat 
TABLE I

\section{Clinical and Pathological Findings in 4 Cases of Nephrotic Syndrome}

\begin{tabular}{|c|c|c|c|c|c|c|c|}
\hline $\begin{array}{l}\text { Case } \\
\text { No. }\end{array}$ & $\begin{array}{l}\text { Age } \\
\text { (yr.) } \\
\text { and } \\
\text { Sex }\end{array}$ & $\begin{array}{l}\text { Duration } \\
\text { of } \\
\text { Nephrosis }\end{array}$ & Oedema & $\begin{array}{c}\mathbf{B P} \\
(\mathrm{mm} \cdot \mathbf{H g})\end{array}$ & $\begin{array}{l}\text { Renal Biopsy } \\
\text { (percutaneous) }\end{array}$ & $\begin{array}{l}\text { Intestinal Biopsy } \\
\text { (peroral) }\end{array}$ & Outcome \\
\hline 1 & $10 \mathrm{M}$ & $1 \mathrm{yr}$. & ++ & $115 / 80$ & $\begin{array}{l}\text { Thickened capillary base- } \\
\text { ment membrane }\end{array}$ & $\begin{array}{l}\text { Several ectatic lymphatics } \\
\text { in villi and among } \\
\text { crypts; ratio of normal } \\
\text { villi to villi with ab- } \\
\text { normal lymphatics } 5: 1 \\
\text { (Fig. 1) }\end{array}$ & $\begin{array}{l}\text { Complete clinical and bio- } \\
\text { chemical remission after } \\
\text { steroid therapy }\end{array}$ \\
\hline 2 & $8 M$ & $8 \mathrm{mth}$. & ++ & $120 / 80$ & $\begin{array}{l}\text { Thickened capillary base- } \\
\text { ment membrane; mark- } \\
\text { ed endothelial cell pro- } \\
\text { lif e r a tion, so me } \\
\text { hyalinized glomeruli }\end{array}$ & $\begin{array}{l}\text { Typical lymphangiectasia } \\
\text { (Fig. 2) }\end{array}$ & $\begin{array}{l}\text { Steroids and 6-mercapto- } \\
\text { purine ineffective; } \\
\text { oedema cleared after } \\
\text { hydrochlorthiazide and } \\
\text { spironolactone, but } \\
\text { blood chemistry un- } \\
\text { changed }\end{array}$ \\
\hline 3 & $4 M$ & 3 wk. & ++ & $105 / 75$ & - & $\begin{array}{l}\text { Lymphatic dilatation in } \\
\text { several villi; ratio of } \\
\text { normal villi to villi with } \\
\text { abnormal lymphatics } \\
7: 1 \text { (Fig. } 3 \text { ) }\end{array}$ & $\begin{array}{l}\text { Complete clinical and } \\
\text { biochemical remission } \\
\text { after steroid therapy }\end{array}$ \\
\hline 4 & $7 \mathrm{M}$ & $3 \mathrm{mth}$. & ++ & $110 / 80$ & - & Typical lymphangiectasia & $\begin{array}{l}\text { Steroids ineffective; } \\
\text { oedema fluctuated; bio- } \\
\text { chemically unchanged }\end{array}$ \\
\hline
\end{tabular}

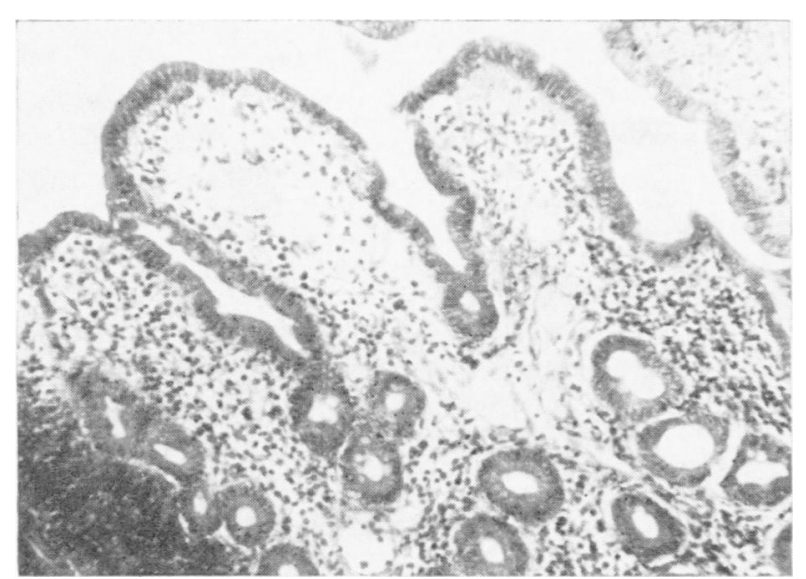

FIG. 1.-Case 1: dilated lymphatics in the villi and among the crypts.

Urine and Blood Findingșin

$\begin{array}{ll}\text { Urine } & \text { Blood }\end{array}$

Creatini

Clearance

Case No.

\begin{tabular}{lc}
\hline Deposit & $\begin{array}{c}\mathrm{Hb} \\
\text { (g. 100 ml.) }\end{array}$ \\
\hline Nil & $12 \cdot 3$ \\
WBC + & $8 \cdot 2$ \\
RBC + & \\
Casts + & $10 \cdot 9$ \\
Nil & $11 \cdot 5$ \\
Few RBC; & \\
few casts & \\
\hline
\end{tabular}

\begin{tabular}{|c|}
\hline $\begin{array}{c}\text { BSR } \\
\text { (mm. 1 hr.) }\end{array}$ \\
\hline 61 \\
79 \\
\\
56 \\
69
\end{tabular}

\begin{tabular}{|c|c|}
\hline $\begin{array}{c}\text { BUN } \\
\text { (mg. } / 100 \mathrm{ml} .)\end{array}$ & $\begin{array}{c}\left(\mathrm{ml} / \mathrm{min} \text {. }{ }_{\mathrm{err}}\right. \\
1.73 \mathrm{~m} 2 \mathrm{~g}\end{array}$ \\
\hline 29 & - $\stackrel{\circ}{\circ}$ \\
\hline 143 & 23.5 \\
\hline 64 & $95 \cdot 3 \underset{\Sigma}{\sigma}$ \\
\hline 17 & ${ }^{88 \cdot 6} \stackrel{0}{\frac{0}{0}}$ \\
\hline
\end{tabular}




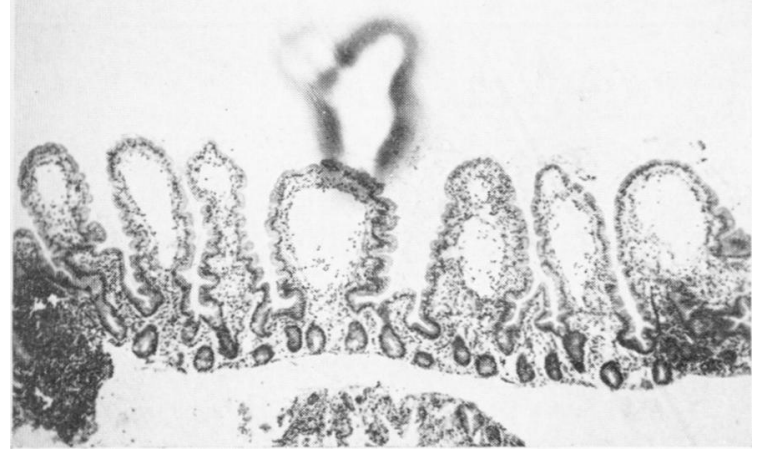

FIG. 2.-Case 2: dilated lymphatics give the villi a ballooned appearance.

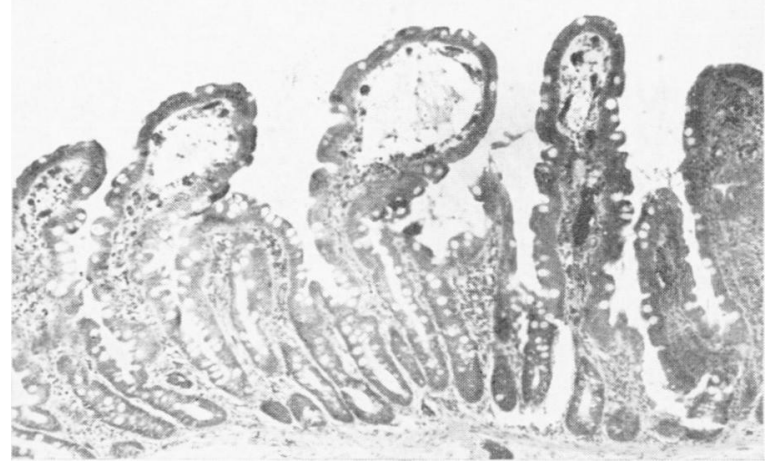

FIG. 4.-Case 4: tip of villi occupied by dilated lymphatics.

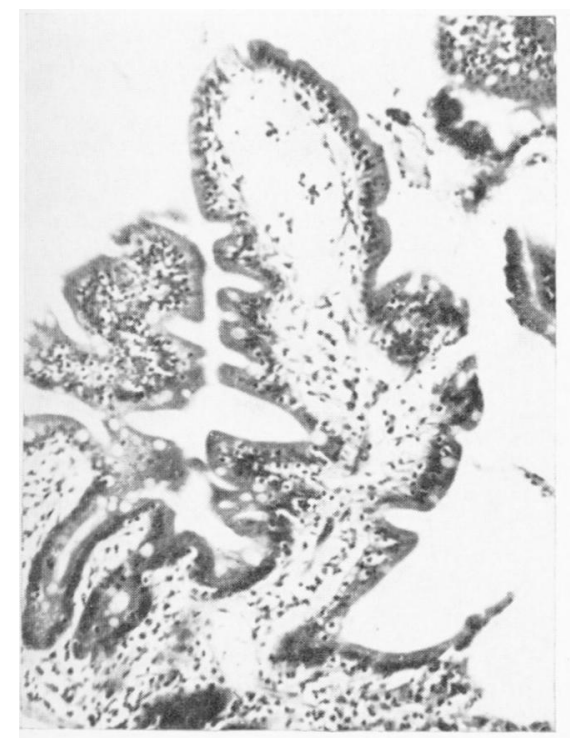

(a)

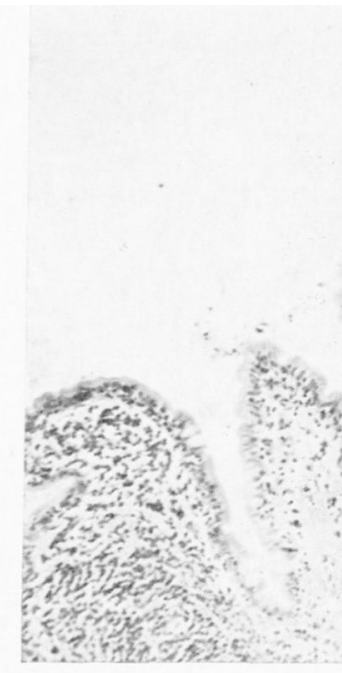

FIG. 3.-Case 3: (a) dilated lymphatic at the tip of the villous; (b) dilated lymphatic following the villous axis.

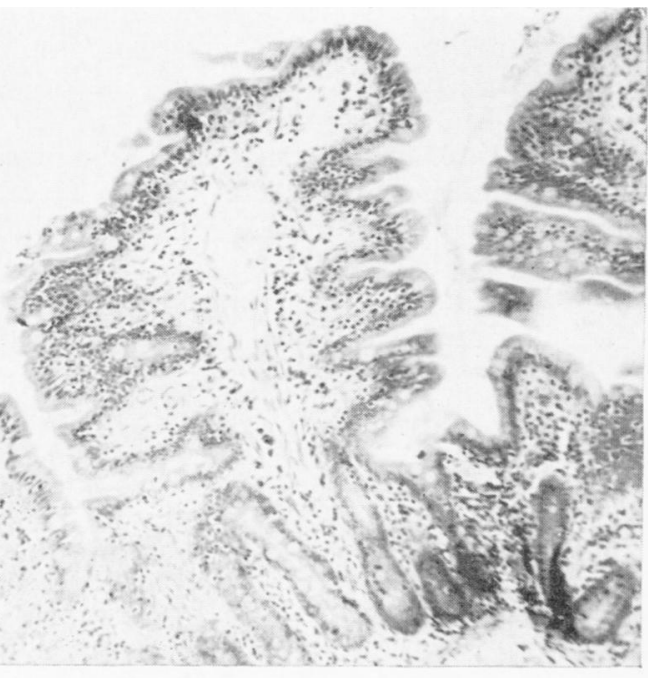

(b)

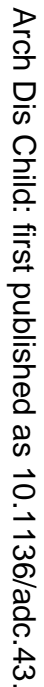

N

जे

옥

$\stackrel{-1}{2}$

$\frac{1}{0}$

․

$\vec{\bullet}$

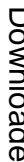

ญำ

Ō



운

금

을

No

N

స్

Serum Protein

Serum Cholesterol

\begin{tabular}{|c|c|c|c|c|c|c|c|}
\hline $\begin{array}{c}\text { Total } \\
\text { (g. } / 100 \mathrm{ml} .)\end{array}$ & $\underset{(\% \text { of total })}{\text { Albumin }}$ & $\left(\begin{array}{c}\alpha_{1} \\
\% \text { of total })\end{array}\right.$ & $\left(\begin{array}{c}x_{2} \\
\% \text { of total })\end{array}\right.$ & $(\%$ of total $)$ & $(\%$ of total $)$ & $\begin{array}{c}\text { Total } \\
\text { (mg./100 ml.) }\end{array}$ & $\begin{array}{c}\text { Esterified } \\
(\mathrm{mg} . / 100 \mathrm{ml} .)\end{array}$ \\
\hline $\begin{array}{l}4 \cdot 25 \\
4 \cdot 5\end{array}$ & $\begin{array}{l}16 \\
14\end{array}$ & $\begin{array}{l}5 \\
5\end{array}$ & $\begin{array}{l}56 \\
60\end{array}$ & $\begin{array}{r}11 \\
9\end{array}$ & $\begin{array}{l}11 \\
11\end{array}$ & $\begin{array}{l}666 \\
691\end{array}$ & $\begin{array}{l}483 \\
391\end{array}$ \\
\hline $\begin{array}{l}4 \cdot 0 \\
5 \cdot 0\end{array}$ & $\begin{array}{l}38 \\
12\end{array}$ & $\begin{array}{l}3 \\
6\end{array}$ & $\begin{array}{l}35 \\
55\end{array}$ & $\begin{array}{l}18 \\
11\end{array}$ & $\begin{array}{r}7 \\
15\end{array}$ & $\begin{array}{l}456 \\
756\end{array}$ & $\begin{array}{l}308 \\
516\end{array}$ \\
\hline
\end{tabular}


TABLE III

Metabolism of Albumin (RISA) in Cases 2 and 4 and in a Control

\begin{tabular}{|c|c|c|c|c|c|c|c|}
\hline & & & & $\begin{array}{l}\text { Half-life } \\
\text { (days) }\end{array}$ & $\begin{array}{l}\text { Total Exchangeable } \\
\text { Albumin (g. } / \mathrm{kg} .)\end{array}$ & Turnover Rate & Faecal Excretion \\
\hline $\begin{array}{l}\text { Case } 2 \\
\text { Case } 4 \\
\text { Control }\end{array}$ & $\begin{array}{l}\cdots \\
\cdots \\
\cdots\end{array}$ & $\begin{array}{l}\cdots \\
\cdots \\
\cdots\end{array}$ & \begin{tabular}{l|}
$\cdots$ \\
$\cdots$ \\
$\cdots$
\end{tabular} & $\begin{array}{l}2 \\
17 \cdot 5 \\
21\end{array}$ & $\begin{array}{l}1 \cdot 7 \\
3 \cdot 5 \\
5\end{array}$ & $\begin{array}{l}459 \mathrm{mg} . / \mathrm{kg} . \text { per day }=27 \% \\
113 \mathrm{mg} \cdot / \mathrm{kg} . \text { per day }=3 \% \\
175 \mathrm{mg} \cdot / \mathrm{kg} . \text { per day }=3 \%\end{array}$ & $\begin{array}{l}136 \mathrm{mg} . / \mathrm{kg} . \text { per day }=13 \% \\
44 \mathrm{mg} \cdot / \mathrm{kg} \cdot \text { per day }=8 \% \\
31 \mathrm{mg} \cdot / \mathrm{kg} \cdot \text { per day }=2 \%\end{array}$ \\
\hline
\end{tabular}

diet or with a diet in which the fat predominantly contains medium-chain fatty acids, the chyle flow may be reduced and the leakage of proteins into the gut minimized (Jeffries, Chapman, and Sleisenger, 1964).

\section{Summary}

Seven children with nephrotic syndrome were submitted to intestinal biopsy. In 2 , the histological picture was typical of intestinal lymphangiectasia and in a further 2 it was consistent with this diagnosis. In 2 of the patients with lymphatic dilatation in the intestinal mucosa, the metabolism of albumin was studied with RISA and the faecal loss of labelled albumin was found to be markedly increased.

It is concluded that in at least some nephrotic children, intestinal lymphangiectasia is responsible for an associated protein-losing enteropathy.

\section{REFERENCES}

Crosby, W. H., and Kugler, H. W. (1957). Intraluminal biopsy of the small intestine: the intestinal biopsy capsule. Amer. $\mathcal{F}$. dig. Dis., 2, 236.

Dawson, A. M. (1965). Protein losing enteropathy. In Recent Advances in Gastroenterology, p. 126. Ed. by J. Badenoch and B. N. Brooke. Churchill, London.

Jeejeebhoy, K. N., and Coghill, N. F. (1961). The measurement of gastrointestinal protein loss by a new method. Gut, 2, 123.

Jeffries, G. H., Chapman, A., and Sleisenger, M. H. (1964). Lowfat diet in intestinal lymphangiectasia: its effect on albumin metabolism. New Engl. F. Med., 270, 761.

Nusslé, D., Barandun, S., Witschi, H. P., Käser, H., Bettex, M., and Girardet, P. (1961). Déperdition intestinale de protéines plasmatiques chez l'enfant. Helv. paediat. Acta, 16, Suppl. 10, 7.

Peterson, M. L. (1963). On the reesterification of fatty acids during absorption of fat: studies in patients with chyluria. Gastroenterology, 44, 774.

Royer, P., Mathieu, H., Habib, R., and Vermeil, G. (1963). Les syndromes néphrotiques de l'enfant. In Les Syndromes Néphrotiques, p. 265. Masson, Paris.

Salazar de Sousa, J., and Cunha, A. (1967). Alguns aspectos da biópsia intestinal na criança. Rev. port. Pediát., 30, 1.

Waldmann, T. A. (1966). Protein-losing enteropathy. Gastroenterology, 50, 420. 